\section{References}

1. Chaoulliv. Quebec (Attorney General). 2005 SCC 35.

2. Sempalis J, Boukas S, Liberman M, Reid T, Dupuis G. Impact of waiting time on the quality of life of patients waiting for coronary artery bypass graft surgery. CMA7 2001;165(4):429-33.

3. Hadorn DC, Holmes AC. The New Zealand Priority Criteria Project. II. Coronary artery bypass graft surgery. BM7 1997;314:135-8.

4. Williams JI, Llewellyn TH, Arshinoff R, Young N, Naylor CD. The burden of waiting for hip and knee replacements in Ontario. Ontario Hip and Knee Replacement Project Team. 7 Eval Clin Pract 1997;3:59-68.

5. Derrett S, Paul C, Morris JM. Waiting for elective surgery: effects on healthrelated quality of life. Int 7 Qual Health Care 1999;11:47-57.

6. Riley AF, Grupcheva CN, Malleck TY, Craig JP, McGee CN. The waiting game: natural history of a cataract waiting list in New Zealand. Clin Experiment Ophthalmol 2001;29:376-80.

7. Chaoulli v. Quebec (Attorney General) 2005 SCC 35 at para 163, Binnie and LeBel JJ, dissenting.

8. Noseworthy TW, McGurran JJ, Hadorn DC; Steering Committee of the Western Canada Waiting List Project. Waiting for scheduled services in Canada: development of priority-setting scoring systems. F Eval Clin Pract 2003;9:23-31.

9. Hadorn DC, Holmes AC. The New Zealand Priority Criteria Project. I. Overview. BM7 1997;314:131-4.

10. Western Canada Waiting List Project (WCWL). The Waiting Time Project. In: Moving forward. Calgary: WCWL; 2005. ch 3. Available: www.wcwl.org /media/pdf/news/moving_forward/report.pdf (accessed 2005 Jul 6).

11. President's Commission on the Study of Ethical Problems in Medicine and Biomedical and Behavioural Research. Securing access to bealth care: the ethical implications of differences in the availability of health services. Washington: US Government Printing Office; 1983.

12. Hadorn DC. Creating a just and affordable system of national health insurance through democratically determined limits on "adequate" and life-prolonging care [dissertation]. Boulder (CO): University of Colorado; 1988 Available: www.davidhadorn.com/thesis.html (accessed $2005 \mathrm{Jul} 6$ ).

13. National Health Committee. Role of the National Advisory Committee on Health and Disability. Wellington (NZ): The Committee. Available: www.nhc.govt.nz /about/rolenhc.html (accessed 2005 Jul 6).
14. Lewis S, Barer M, Sanmartin C, Sheps S, Short SED, McDonald PW. Ending waiting-list mismanagement: principles and practice [editorial]. CMAJ 2000;162(9):1297-300.

Correspondence to: Dr. David Hadorn, 282 Mt. Fyffe Rd., Kaikoura NZ; dhadorn123@fastmail.fm

Appendix 1: Example of patient description based on WCWL criteria provided to participants to estimate "maximum acceptable waiting times" for patients with different degrees of clinical urgency ${ }^{10}$

A patient with hip or knee arthritis has:

- Severe pain on motion (e.g., while walking or bending)

- Moderate pain at rest (e.g., while sitting or lying down)

- Ability to walk less than 1 block without significant pain

- Severe limitations (e.g., unable to perform most activities, such as putting on shoes, managing stairs, standing from seated position, sexual activities, bathing, cooking, recreation or hobbies)

- Severe abnormal findings on physical examination related to affected joint

- Ability to fulfil their role and independence in society that is threatened but not immediately (e.g., ability to work, care for dependents or live independently)

Note: $\mathrm{WCWL}=$ Western Canada Waiting List Project.

\title{
The private sector in the English NHS: from pariah to saviour in under a decade
}

\section{Richard Smith}

ß See related articles pages 269, 271, 275 and 277

I must make it clear that I am writing about the NHS in England only. Health is a "devolved" issue, and the health services in the 4 countries of the United Kingdom are rapidly diverging.

$\mathrm{U}$ ntil recently the private sector played an unimportant part in England's health services. Well over $95 \%$ of interactions between a patient and doctor took place in the public sector. Private general practitioners existed only in isolated pockets. Emergency hospital care was all in the public sector, and the private sector was concerned mainly with elective surgery. Patients "went private" simply to jump queues. Now - suddenly — the government is looking to the private sector to save the National Health Service (NHS), causing many to worry that the NHS is to follow airlines, telecommunications and railways into the private sector. Why the change?

Margaret Thatcher, the queen of privatization, didn't dare privatize the NHS. Instead, she said that she wanted to make it so good that nobody would need the private sector. Despite being a risk taker, she went against her ideological instincts because she knew that the NHS mattered too much to the English. Our belief in it is almost religious - despite the fact that it embodies socialist values that were dominant in 1948, when the NHS was founded, but have disappeared from much of English life.

The relationship between the public and private sectors in health care has been complicated since the start of the NHS. General practitioners were from the beginning "independent contractors" rather than employees. But nobody has thought of them as being in the private sector, and they enjoy a generous NHS pension.

Chunks have been falling off the NHS and into the private sector almost since the beginning. Glasses were the first to go, and dentistry soon followed. Some in England (including me) are privileged to have an "NHS dentist," although we still have to pay something, but most dental pa- 
tients have to pay the full cost of treatment. The biggest transition was when long-term care moved to the private sector. When I was a junior doctor in the 1970s, the NHS had many huge hospitals (perhaps better called warehouses) full of long-term, elderly patients. Now those hospitals are gone, and people have to sell their houses in order to fund long-term care. The state will pick up the bill only once you are destitute or if you need "nursing care" rather than "social care," giving rise to lots of complicated debates about whether a bath is a "social bath" or a "nursing bath."

These changes didn't evoke political crises - because medical care, seeing a doctor, stayed mainly in the public sector. Anxiety did, however, begin to mount among those on the left as in the mid-1990s the "private finance initiative" became the main way of building much-needed new hospitals. Under this scheme, the private sector finances and builds the new hospitals, but with a contract from the government promising to pay to use the hospitals for some 30 years. The Tories developed the idea - to a chorus of criticism from the Labour opposition - but when Labour came to power in 1997 it quickly adopted the policy.

Labour, however, remained firmly opposed to further private sector involvement in the NHS - until protests about the state of the NHS reached a crisis point, forcing the prime minister to promise in 2000 that he would increase funding of the NHS from $7 \%$ of gross national product to the $9 \%$ European average. This money is currently being transfused into the NHS.

More money alone will not fix the problems of the NHS, including the long waiting lists for elective surgery. The government recognized that it needed more capacity (more doctors, nurses and operating theatres) and more incentives to encourage efficiency, increased productivity, and improvement in the quality of care. It realized that the private sector could help with both capacity and incentives - and so the private sector came to be seen (at least in New Labour circles) as not the nemesis of the NHS but, rather, its saviour.

Another Tory idea that Labour eventually revisited after coming to power was the idea of increasing competition by creating an "internal market" for the NHS, whereby "purchasers" and "providers" would be split and the providers would compete, thus employing market forces to raise quality and reduce costs. Thinking about how government could get maximum value for the large sums it was spending on the NHS, it - perhaps inevitably - returned to the idea of the internal market (while carefully avoiding the phrase). The government also recognized that "plurality of provision," including private providers, could increase competitive pressure on NHS providers and encourage innovation.

So began the courting of the private sector. A modest increase in capacity could be achieved quickly by using existing private hospitals to operate on NHS patients, but a dramatic increase in competitive pressure has had to wait for the appearance of "independent treatment centres," which are built by private providers under government contracts. Most of these centres are being provided by companies from outside England, underlining the general impression that English private providers have been slow and sleepy, existing in a small, cosy, relatively noncompetitive market. (Ironically, the traditional private market in England faces a crisis as NHS waiting lists come down and people have no reason to go the private sector.)

The competitive pressure inside the NHS is being increased by the introduction of "payment by results" and "choice." Hospitals, public or private, will soon be paid a national tariff for treating all patients by HRGs (healthcare resource groups, the British version of diagnosis-related groups), and patients needing hospital care will be presented with a choice of 5 hospitals, including 1 private one. Hospitals that can attract patients and treat them for less than the national tariff will flourish, but what will happen to the others? Will they close? Closing hospitals makes politicians nervous, and at least one politician has lost a safe seat because of closure of the local hospital. An alternative to closure might be a takeover by a private provider.

The government is also looking to bolster purchasing (or commissioning, as it's now called), again by going back to the future. The Tory government gave general practitioners a budget to buy hospital care for their patients, a scheme called "GP fundholding." Labour abolished the scheme because it led to inequity but now has introduced "practice based commissioning," whereby GPs or groups of GPs will purchase and redesign all services, including hospital services, for their patients. This scheme is being introduced because existing commissioners (public organizations that are responsible for the health of defined populations of about 200000 people) are weak. Private companies might well become involved in commissioning, and some are already providing data systems to enable commissioning.

The enthusiasm for competition is also leading the NHS to look at private provision of general practice, something that seemed unthinkable until very recently. Indeed, the rhetoric coming from the Department of Health is about an "NHS of values not institutions." In other words, what needs to survive is not necessarily the NHS itself but, rather, the values it embodies - of universal coverage, being free at the point of access, and providing care of equal quality for all. It might soon be in England that the financing and regulation of the health service remains with the government but that the provision and management of the service lies increasingly with the private sector. In under a decade, the private sector has turned from being a pariah to a saviour.

Richard Smith is chief executive of UnitedHealth Europe in London, UK. From 1991 to 2004 he was the editor of the BMJ and chief executive of the BMJ Publishing Group.

Competing interests: Richard Smith is chief executive of UnitedHealth Europe, a company founded in 2004 by the US-based UnitedHealth Group to work with the NHS and other public health systems in Europe.

Correspondence to: Dr. Richard Smith, UnitedHealth Europe, 15 Greycoat Place, London UK SW1P 1SB;

Richard_s_smith@uhc.com 